Article

\title{
Sport, Islam, and Muslims in Europe: in between or on the Margin?
}

\section{Mahfoud Amara}

School of Sport, Exercise and Health Sciences, Loughborough University, Loughborough, Leicestershire, LE11 3TU, UK; E-Mail: M.Amara@lboro.ac.uk; Tel.: +44-0-1509-226370;

Fax: +44-0-1509-226301

Received: 30 September 2013; in revised form: 30 November 2013 / Accepted: 4 December 2013 / Published: 10 December 2013

\begin{abstract}
The aim of this paper is to reveal how misconceptions-or using the concept of Arkoun, "the crisis of meanings"-about the role and position of Islam in Europe is impacting on the discourse on sport, Islam, and immigration. France is selected as a case study for this paper as it is in this country where the debate on religion in general and Islam in particular seem to be more contentious in relation to the questions of integration of Muslim communities to secular (French republican) values. Recent sources of tensions include the ban of the Burqa in the public space; the debate on national identity instigated by the former French president Nicholas Sarkozy, which became centred around the question of Islam and Muslims in France; the provocative cartoons about Prophet Mohamed in the satirical magazine Charlie Hebdo; opposition against the provision of halal meal in France's fast-food chain Quick; and resistance toward Qatar's plan to invest in deprived suburbs of France, to name just a few. The other context which this paper examines in relation to the question of sport, Islam, and identity-making of Muslims in Europe is the phenomenon of "reverse migration" or the re-connection of athletes of Muslim background in Europe, or so-called Muslim neo-Europeans, with their (parents') country of origin. The paper argues that sport is another highly politicised space to judge the level of "integration" of Muslim athletes in European societies, and the degree of “religiosity” in their (parents') country of origin.
\end{abstract}

Keywords: sport; Islam; identity; Muslims; France; suburbs; reverse migration 


\section{Introduction}

The question of religion in Europe, particularly Islam, has been defined to certain extent around the following dichotomies: homogeneity versus cultural diversity, private versus public spheres, and belief versus disbelief. The question of sport and religion (including Islam) is also shaped by these discourses impact on other debates such as accommodating sport to religious needs (or vice versa), and access to public funding and sport facilities by Muslim communities [1,2]. There have been a number of questions raised in Europe, and more recently in Canada (particularly in Quebec), around the use of tax money to fund sport projects targeting Muslim communities only; the expression of religiosity, for instance wearing the veil (or even turban for Sikhs); and the issue of sport practice in schools in a mixed gender environment [3].

Muslims in the West are facing multiple dilemmas concerning the complexity of combining multiple identities: sense of belonging to Islamic Ummah (community of Muslim believers) and sense of belonging to host societies or countries of birth. They are under pressure more than before to demonstrate their loyalty to Islamic religion on the one hand, and to their nationality/citizenship, on the other. Césari explains this complex variety of belonging(s) as the contradiction between individual, collective, and national identities. These complex, and for some contradictory, layers of identity are being felt in the domain of sport, particularly in sport such as football and sports events, such as the FIFA World Cup and the summer Olympics. Demands are being made by Muslim communities-in the name of democracy, citizenship, and rights to cultural and religious differences - to accommodate specific times for Muslim women and young girls at local leisure centres, to allow men to wear long swimming trunks in public swimming pools, and to allocate specific training/nutrition programmes for professional athletes to meet their religious duty of fasting during the Month of Ramadan. For Muslim Europeans, sport is another field to explore (or to "conquer") in order to reconcile their multiple identities, or succeed. For conservative-nationalist movements and states authorities in Europe sport is another public (secular) space to safeguard from the over-expression, or over-visibility, of Islamic identity in Europe [4].

In terms of structure, the paper will first discuss the question of religious phenomenon in Europe in relation to the debate of cultural diversity, ethnicity, and citizenship rights. The second part of the paper examines the question of Islam and Muslims in the West in general and in France in particular. The last part of the paper reveals examples of tensions around Islam and Muslim communities in the domain of sport. The media portrayal of athletes of Muslim background in the country of birth or citizenship, but also in the country of origin, are used as illustrative examples of the crisis of meanings today around Muslim faith and culture in Europe.

\section{Religious Phenomenon in Europe: "Ritual” versus “Cultural”, "Particular” versus "Universal”}

\section{According to Touraine:}

What is new today, is that groups previously defined on the basis of their nationality, ethnicity or religion, which had existed only in the private sphere, are acquiring today a public existence so strong that it risks damaging their belonging to a national society...(this is taking place) whilst we are witnessing the weakening of national communities and the strengthening of ethnic communities ([5], p. 235, translated from French). 
In Touraine's terms, we should not confuse the tendency toward cultural plurality, linked to growing international migration, with communautarisme, ${ }^{1}$ defined in the strictest sense by the power of the ruling group in imposing practices and internal restrictions on their community members, which in Touraine's terms “usually takes the form of a rejection of everything that is foreign”. In this sense communautarisme, which is commonly used in France to refer to self-segregation of certain communities, defines itself in opposition to citizenship, limiting the civic rights of men and women and therefore contradicting the political rights of individuals. Touraine here prefers to refer to "cultural rights" (the particular), which are positively linked to (and do not contradict) "political rights” (the universal). Moreover, as argued by Touraine, “cultural rights", like "social rights”, can become anti-democratic and even totalitarian instruments if they are not closely associated to "political rights", which are universal. Touraine [6] concludes:

Multiculturalism does not mean the endless fragmentation of cultural space, and it is not a world-wide cultural melting pot. It is an attempt to reconcile the diversity of cultural experiences with the mass production and distribution of cultural goods... No multicultural society is possible unless we can turn to a universal principle that allows socially and culturally different individuals and groups to communicate with one another ([6], pp. 166-67, translated from French).

It should be noted here that Touraine strongly believes in modernity as the only possible platform for a cross-cultural dialogue between societies which have reached modernity and those which have certain elements of modernity but which are yet to fulfill their modernisation. Accordingly, Touraine asserts that "the Other has to be recognised as such, as different, only if the same Other, as myself, accepts the universal principles which define modernity” ([5], p. 263). This is problematic when we know the role that modernity and the enlightenment movement in Europe played in reducing religion to its cultural expression in the private sphere. The intellectual disqualification of religious reason in the past by scientific reason (at least in its anti-clerical version) ${ }^{2}$ has contributed to what Arkoun [7] describes as "the generalisation of a culture of disbelief" in western societies. This is even more problematic for Islamic religion, which does not disassociate between the ritual, the moral, and the law (the dimensions of Islamic legality), on the one hand; and between the public and the private spheres, on the other. Oubrou explains:

The fact that the Koran tackles the principle of sanction, responsibility, obligation of laws as regards to family...it means that Islam is interested in the supervision of life in society and community. It is thus a foundational principle in the existence of an Islamic law ([8], p. 130, translated from French).

For Ramadan, “whether we like it or not, the essence of Islam is religious”:

The central principle of tawhid, which we have often referred to, the foundations of faith and practice, the general guidance we find in the scriptural sources, leave no room for doubt about the reality of this. To speak

1 Communautarisme, is defined as anti-liberalism doctrine. The concept becomes mainly applied today in France relation to the over visibility of Islamic religion in the public domain (praying in the streets, the provision of halal meals in school and in the market, or wearing the veil in public offices) which for some is not compatible with, and even a threat to, the republican values (or republicanisme) and cohesion within French national community.

2 So called 'tele-techno-scientific' is spreading a new pragmatic instrumental form of reasoning lead by the principle of 'just do it', as long as so doing ensures concrete, significant technological and economic success. 
of Islam is first of all to speak of faith, spirituality, and ethics, which together make up a conception of humankind and of life (...). Around the body of principles that define the fundamentals of allegiance to Islam, the area of social affairs is a field that is open to the cultures, customs, discoveries, and creativity of human kind as long as they do not violate a prohibition that is specific and explicit and recognised as such ([9], p. 214).

Notwithstanding the dominance of secular discourse in science, politics, and the media, many commentators agree that there is a global resurgence or revitalisation of religious movements, including Islam, which started according to Riesebrodt in the 1970s [10]. Habermas recognises that we are in "post-secular” epoch. In his article "Notes on a Post-Secular Society" he asks about the current place of religion in Europe, how should we see ourselves as members of a post-secular society and what must we reciprocally expect from one another in order to ensure that in firmly entrenched nation-states, social relations remain civil despite the growth of a plurality of cultures and religious world views. To answer these questions, Habermas proposes that a distinction should be made between "secular" and "secularism":

Unlike the indifferent stance of a secular or unbelieving person, who relates agnostically to religious validity claims, secularists tend to adopt a polemical stance toward religious doctrine that maintains a public influence despite the fact that their claims cannot scientifically justified.

Habermas goes on to describe the main features of "post-secular" modern societies as follow:

- The awareness of living a secular society is no longer bound up with the certainty that cultural and social modernisation can advance only at the cost of the public influence and personal relevance of religion.

- Religion is gaining influence not only worldwide but also within national public spheres. Churches and other religious organisations are increasingly assuming the role of "communities of interpretation” in the public arena of secular societies:

They can attain influence on public opinion and will-formation by making relevant contributions to key issues, irrespective of whether their arguments are convincing or objectionable... Let me remind you that the visibility and vibrancy of foreign religious communities also spur the attention to the familiar churches and congregations. The Muslims next door force the Christian citizens to acknowledge to the practice of a rival faith. And they also give the secular citizens a keener consciousness of the phenomenon of the public presence of religion [11].

\section{3. 'Islam' and 'Muslim identities' in the West}

According to Arkoun, the imposition of positivist scientific knowledge, which happened in Western society in the name of secularism (or laïcité in France), liberalism, and socialism, has 'discredited' or 'eliminated' religion in society without providing an adequate alternative as a symbol of human existence and a source of unifying ethical values for the group [12].

One can argue, however, that despite the apparent triumph of secularism, the division between the transcendent and the temporal is not always explicit. Sometimes the Judeo-Christian tradition of Europe is used as an argument to justify the incompatibility between Islam and European culture ${ }^{3}$.

3 For example, debate around the question of the integration of Turkey into the EU; it is worth noting here that Turkey is accepted as part of the European space in sport but not in the cultural and political spaces. 
Secularism means different things in different national contexts. The same is true for the relation between the state and religion (including Islam). Regarding this point, Césari asserts that the relationship of the government to religion in Europe, and thus the institutionalisation of Islam, tends to pattern itself on one of the three principles: cooperation between church and state (Austria, Belgium, Italy, Spain, and Germany); the existence of state-sponsored religion (Great Britain, Denmark, and Greece); or the 'total' separation of religion and politics (the case of France) [4].

The second source of incomprehension about the 'others' (i.e., Islamic faith and Muslims culture) lies in what Said refers to as Orientalism [13]. The construction of Islam, in the Western/collective imagination, is argued to be a product of opposition between, or in contrast to, the East/Orient/Islam on one side, and the West/the Occident/Christendom on the other. As result of this antagonistic differentiation, Islam and the 'Orient' as depicted in the West have been reduced to a set of references and characteristics, linked to “a collective fiction” which sees the 'Orient' as a place of 'violence', 'superstition', and 'irrationality' [14].

The third cause of incomprehension lies in the discourse on identity (of 'we' and 'others') in the so-called era of globalisation, which has increased, according to Habermas (cited in Borradori, 2003), the sense of fear of "the violent uprooting of traditional ways of life". The tendency toward an exclusive-oriented approach to identity within 'immigrant' communities, but also within 'non-immigrant' national minorities, has also been reinforced by the absolutist discourse of nationalist populist movements. The discourse of exclusion, fuelled by fear from increasing migrant flows, has been used by nationalist parties across Europe to portray the foreign 'others' (ethnic minorities, religious communities, refugees, and asylum seekers) not only as guilty by virtue of their "foreignness", but also by their cultural heritage [14].

The other aspect in this crisis of meanings is in the dialectic of Muslim 'authenticity'. Who is an 'authentic Muslim' and who is not? The Muslim community, at least for those accepting to be categorised as such due to their cultural background or their religious worldview, can be divided in relation to the question of authenticity (negotiated in relation to the Quranic fact and the authentic tradition of the prophet and his companions and early followers) into mainly six groups (see Table 1). To add to these six groups there is a growing minority represented by Western-converted Muslims, defined by Charnay [15] as European neo-Muslims, which he distinguishes from Muslim neo-Europeans representing the second and third generations of Muslims in Europe.

One should also distinguish between Islam as a religion, and what Akbar refers to as Muslims' responses to the forces of globalisation, actions, and strategies that Muslims are adopting as a result of their current political or economic situations as a minority in non-Muslim societies. Akbar categorises these responses into "accepting” (reaching out to other faiths), "preserving” (traditionalists), and "synthesising" (synthesising with other non-Muslim and secular systems) [16]. To illustrate the different strategies that Muslims adopt in mobilising Islam (or not) as a frame of reference Mandville provides the following example:

There are a good number of Muslims involved in social and political movements who take the pursuit of goals and agendas defined in terms of Islamic normativity (interpreted in widely varying ways) as their primary raison d'être. Likewise, there are also many Muslims whose public identities under most 
circumstances are not constructed in reference to Islam, but who -under certain conditions-may mobilise themselves around Islam as a form of political expression ([17], p. 493).

Last, component in the crisis of meanings is Occidentalism. In opposition to the Orientalism, another form of exclusivism has emerged, namely 'radical Islamism', which purports to be the sole 'owner' of Islam and which builds its identity exclusively in relation to the 'other', 'evil', 'atheist', 'imperialist', 'fashion-addicted', 'selfish', 'morally corrupt' West, as the (sole) cause of 'our' (Muslim societies) decadence. This dehumanising picture of the West is characterised as the root of anti-Western sentiments [18].

Table 1. Muslim identity and Islamic 'authenticity’ in the West ([15], p. 21).

\begin{tabular}{cl}
\hline \multirow{2}{*}{ Ritualised Islam } & $\begin{array}{l}\text { Islam of grandparents (first generation of immigrants) the holder of traditions } \\
\text { in the family. Visible during religious celebrations and in dress codes. } \\
\text { Authenticity is defined in relation to Islamic practices of the country of origin. } \\
\text { Islam as a spiritual ethos. }\end{array}$ \\
\hline \multirow{2}{*}{ Nationalist Islam official Islam of the country of origin represented by the ministry of } \\
religious affairs and its delegate in Europe. \\
Islam in the service of state (secular) ideology (Moroccan, Turkish, Algerian) \\
and source of legitimacy for the political order (nation-state, economic, \\
cultural and social projects).
\end{tabular}

\section{Sport and Muslims in Europe: Case Study of France}

According to Pew Research data from 2010 on Religion in Europe, the number of Muslims in Western Europe has reached 11.3 million. The Muslim share of Western Europe's total population is expected to increase from $6.0 \%$ in 2010 to $8.6 \%$ in 2030 [19]. In the absence of census data for ethnicity and religious affiliation, Islam is considered to be the second largest religion in France. Although it is hard to get a precise picture about the number Muslims in France, including French citizens of Muslim heritage and other Muslim residents, it is commonly accepted that their 
number is around five to six million (8\%-9.6\%), the majority of whom are of North African origin (Algeria, Tunisia, and Morocco, known as the Maghreb). The rest are mainly from sub-Saharan Africa and Turkey.

Islam, as the "second largest religion following Catholicism", often finds itself at the heart of the debate in France about national identity, secularism, migration, national security, and riots in the suburbs (the banlieues or underprivileged housing estates). As described by Césari:

Too often discussions about Islam in France begin and end with a treatment of Muslims as a social problem.

Too often the question is asked: Can Muslims fit into French society? That question presupposes that Islamic values are inherently incompatible with western ones and that Muslims constitute a “dangerous class” [20].

The French republican reassertion of the need to conform to the non-religious nature (known as laïcité) of the state has been reinforced by the ban on wearing of religious symbols in schools. Such a ban on public displays of religious affiliation also implies that such dress or religious symbol would be unacceptable in public sector sports facilities and services. As a consequence, the questions of the veil and the demand by members of the Muslim community for women only swimming hours at municipal swimming pools are becoming the centre of electoral campaigns. This is to measure the loyalty of candidates for different elections at local and national levels to the French republican value of laïcité. Martine Aubry, previously the head of the socialist party and the mayor of Lille, was highly criticised for allowing the allocation of specific time for women (mainly Muslim) in a public swimming pool [21]. She and the socialist party have been accused by conservative party and far right movements of seducing electorates among Muslim communities at the determent of secular values of France and its assimilissionist/republican model.

Having described the general context about the debate on Islam in France, we will explore in the subsequent section some of the emerging discourses that characterise media depiction of the question (or the problem) of Islam and/in sport. A number of events that occurred lately in France are worth exploring from a sociological, political, and media point of view in order to make sense of the debates on sport in relation to wider societal issues such as the politics of identity or questions of integration, diversity and laïcité in France and its former colonies in North Africa.

\section{1. "Moderate" versus "Radical” Islam}

In an interview with a French radio station, the philosopher Alain Finkielkraut asked the following question about French residents of North African background: What do they think of France? He noted:

We have the impression that the imaginary identity is Algerian and France is just an insurance company, and at most, an object of execration. It is for this reason that the campaign of French identity is a success in France. Some say that such affirmation of identity is exclusionary. No! We invite all French citizens to share this identity and there are some who aggressively and firmly reject it. ([22], translated from French)

Media coverage and political commentaries around selected incidents are symptomatic of the crisis of meanings, which we explained earlier about Islam and Muslim identities in Europe in general and in France in particular. The first incident occurred during the final of the 2006 FIFA World Cup in Germany between France and Italy. Zidane's famous headbutt of Metarazzi, a global media event par 
excellence, experienced by millions of spectators, was explained as being the by-product of a 'clash of civilizations.' On the one hand, Zidane, with his Algerian immigrant origin, somehow represents the Muslim World. He grew up in a suburb of Marseille, which is known for its multi-cultural population. On the other hand, Metarazzi, the Italian player, was representing 'the West.' Zidane's reaction was explained in orientalist fashion as 'irrational' and symptomatic of his 'hyper-masculine' North African culture and delinquent-like culture of les banlieue or suburban zones of Marseille [23]. Similarly Jiwani contends that French coverage of the incident reproduced "Orientalist frames (animal imagery, violence, and irrationality) but also underscored associations between Muslims and terrorists in its speculations regarding what Marco Materrazi had said to provoke Zidane’s actions” ([24], p. 1).

The second incident occurred during the friendly match between Tunisia and France on 14 October 2008 in Stade de France. France's national anthem, La Marseillaise, sung by Laam, a French female R'n'B singer of Tunisian origin, was booed by some in the crowd. This scandalised and even enraged French politicians, particularly those from the center-right majority, led by President Sarkozy, who not only asked for an investigation into the matter, but also requested that measures be put in place to prevent the reoccurrence of such an event in French territory. Some of the measures presented in response to this demand stipulated that all friendly games with the country concerned are to be suspended for a period determined by the president of the federation or, even more drastically, that France should no longer play friendly matches against countries from the Maghreb region. Of course, this incident was an occasion for some in political, football, and intellectual circles to question the loyalty of the Maghrebi community (Tunisian, Algerian, and Moroccan) to the French nation and its values. When asked by the media to comment on the incident, Hatem Ben Afra, born in France of Tunisian parents and later a member of the French national football team, declared: "it's a bit of a shame but it's not a major problem. They need to exist, you have to understand them” [25].

The third incident was during the 2010 FIFA World Cup in South Africa. In the midst of the scandal of the French football team, the image of Franck Rebery's wife, with her Algerian flag and t-shirt displaying the slogan 'Yes, We Can' in support of the Algerian national team, was at the centre of another polemic in France. Her loyalty to France, and thus the loyalty of her husband (a Muslim convert), were put in doubt. In her campaign to replace her father, Jean-Marie le Pen, as the new leader of the far right National Front Party, Marine le Pen declared:

Most of these people think that one day they can represent France in the World Cup, and another day they can consider themselves to be from another nation or to have another nationality [...] if they behave correctly [...] if we sometimes hear about patriotism from these players, if it happened that some of them do not refuse to sing La Marseillaise, and they do not taking on the flags of other countries, maybe things will change. But currently, I do not particularly recognize myself in this team. ([26], translated from French)

The misconduct in South Africa of some players, such as Anelka and Rebery (both Muslim converts) was portrayed in the media and within political circles as a product of the "violent", "non-French", and "non- republican” culture of suburbs that are mostly populated by French of immigrant decent and particularly of North African origin. This was re-emphasised in the intervention of the French Minister of Health and Sport, Roselyne Bachelot, during a parliamentary debate about the French National Team: 
The government should never have had to get involved in the World Cup, but you have all seen the disaster that resulted from immature thugs leading frightened players, a coach without authority, and a federation that's out of its depth. That's why the government has decided to take charge [27].

Finkielkraut, the French Philosopher, went a step further by explaining, yet again, the reasons behind the fiasco of the French team in South Africa: "the French team suffers from ethnic and religious divisions... it is a team of hoodlums... with mafia ethics... a team of people who don't care about France” [28].

In light of the media pressure to protect the secular values of the French Republic within the national football team, particularly after the bad publicity of Les Bleus in South Africa, Lauren Blanc, the new appointed coach, declared in an interview that halal meals will not be provided at the national performance centre or during training camps [29].

\subsection{Living in between}

When asked about their identities either in their country of birth or country of origin, athletes from immigrant backgrounds are torn between a symbolic connection and a deeper connection with the country of origin. This is exemplified by a statement made to the media by Jamal Bouras, the French Judoka (from an Algerian background) and a gold medalist in the 1996 Atlanta Games: "What does it mean: French Jewish, Arabs... who are the Arabs? Am I Arab or French? I am French Muslim!” ([30], translated from French). ${ }^{4}$

For some French citizens of immigrant origin, sport (particularly soccer) is an occasion to celebrate their double sense of belonging to a 'hybrid' identity - that is, an amalgam of aspects of migrant culture and French citizenship, expressed neither in terms of fully belonging to 'French culture' nor in terms of belonging to 'culture of origin. However, due to the sentiment of being marginalised in their country of birth or to improve their international career, other athletes from immigrant decent choose to represent their country of origin at international sport arena. This is evident in the steady increase in the number of third-generation young players from immigrant communities in North African national teams (Tunisia, Morocco and Algeria). If we take the example of Algeria, the number of players with an immigrant background participating on the Algerian national football team has increased. This increase has been facilitated by the new FIFA rules. ${ }^{5}$ These players are principally from France and Belgium, which are known for high concentrations of residents with Algerian immigrant origins, but also from other countries such as Holland, Denmark, and Canada. One can argue that, for these athletes, participating with the Algerian national team represents a unique opportunity to compete at international level. The same pattern can be seen in other North African countries and in the Middle East, particularly in Palestine and Lebanon, which have large immigrant communities in Europe and North America [31].

4. It was reported that after winning the Gold Medal in Atlanta Jamal Bouras offered his medal to "all Muslims who suffer in the world". This provoked a number of comments in mainstream media and in social media about his ideology. He was even accused by extreme right circles of being pro-Palestinian Hamas and pro-Lebanese Hezbollah.

5 The example of Rais Mblouhi, the goal keeper of the Algerian national football in the 2010 FIFA world, born in France to a Congolese father and Algerian mother. 
The reintegration of top athletes into the national team of their parents' country of origin is not always celebrated in a positive way. In addition to the fact that these players are subjected to criticism in their countries of birth, as discussed earlier, their identities and loyalties are also questioned in the country of origin, particularly when the performance expected from them is not there. The Algerian national team that qualified for the 2010 FIFA World Cup in South Africa, after 24 years of absence, was depicted as 'the other French team'. They were asked to prove more than other players, their loyalties to the Algerian flag and to demonstrate their Algerian "male aggressiveness" during the competition and their faithfulness to Islamic morality (for instance abstaining from alcohol). The fact that some players tinted their hair blond for the opening group game between Algeria and Slovenia was severely criticized in the Algerian media and was described as 'non-Algerian,' 'non-Arab' (Algeria being the only Arab country in the competition), and even 'non-Islamic.' To counter these stereotypes and to affirm their attachment to Islamic morality players make Sujud (prostrations) after scoring a goal [31].

Top athletes who choose to compete for their country of birth are still celebrated as 'ambassadors' of their country of origin, and their performance is explained as a direct product of the creativity, courage, and intelligence they inherited from their culture. Zidan, Nassri, and Benzima have been praised for their 'Algerian,' Ben Arfa for his ‘Tunisian,' Affelay and Boulehrouz for their 'Moroccan' style of football; Mehdi Baala_French middle-distance runner-for his natural 'North African' ability to run. By contrast, in their country of birth, these athletes' performances are explained as a direct result of (Western) discipline, rational and strategic thinking and socialization (de-culturation) in schools. However, sometimes the Western culture of these top athletes is not well accepted in their country of origin. Sometimes, these players are even deemed heretics. A Tunisian newspaper, Attounisia, published a revealing picture of a Tunisian-German player, Sami Khedira, with his model girlfriend, Lena Gercke. The photograph generated a state of shock in Tunisia. Mass demonstrations, led particularly by the Salafi movement, were organised in the country. As a result three journalists from the newspaper were taken to custody and charged for offending public morality. This is happening while Tunisia is undergoing a political transition and societal transformations characterised by the resurgence of religiosity (tadayoun) after more than three decades of secular rule under Bourguiba and Ben Ali. Following international pressure, the charges against the journalist were dropped, but the incident sparked a national debate in the country about the limits of freedom of expression and morality [32], as well as the debate on national identity in the post-Ben Ali era.

\section{Conclusions}

Sport is at the centre of the debate on integration and national identity of immigrant communities in Europe, and since 9/11 the debate is now centred on immigrants of Muslim faith or culture. For Muslim athletes sport, and particularly football is a terrain for identity making and resistance against stigma. The incidents in sport involving Muslim athletes is an occasion for the supporters of clash of cultures exacerbate existing ethnic tensions in cases that involve athletes of immigrants and Muslim background, mixing thus in their interpretation aspects of "violence, Islam, and masculinity".

For Muslim athletes, playing for their country of origin is an occasion to reconnect with Islamic culture, or at least Islamic spirituality, and to support important causes of the Muslim Nation 
(Oumma). The example of Frederic Omar Kanoute, French of Mali origin and professional footballer with Seville FC, who was fined 3000 Euros by the Spanish Football Federation for revealing a T-shirt displaying a pro-Palestinian slogan. Similar to Kanoute, more top professional footballers in Europe are celebrating their Muslim identity in public. This, in turn, create tensions with regards to competition and fasting during Ramadan or sponsorship of football clubs by alcohol and betting companies [33]. ${ }^{6}$

Some media and intellectual commentators explain public expressions of religious identity in France, including in sports, as a means of defying France's secular republican values. Such explanations accompanies incidents ranging from providing halal meals in football training camps to Jamel Bouras's gesture of offering his Olympic gold medal to "Muslims around the world". These same commentators frequently interpret public expressions of religious identity in sports as symbols of religious awakening and the 'Islamisation' of French suburbs. "The religious belief is more structured than the belief in republican values”, wrote le Monde (October 4, 2011) after the 2011 riots to explain the phenomenon of "cultural re-islamisation "or "intensification of religious practice” among Muslims in France [34].

Sport is becoming the space to test the success of "integration" policies of minorities into the host society and to question the loyalty of Muslim minorities to the "host" nation. Muslims of immigrant origin are caught between affirming their (multiple) identities while avoiding and combating stigmatisation both in their country of birth and country of origin.

\section{Conflicts of Interest}

The author declares no conflict of interest.

\section{References}

1. Kirstin Walseth. "Young muslim women and sport: The impact of identity work.” Leisure Studies 25 (2006): 74-94. doi:10.1080/02614360500200722.

2. Mahfoud Amara, and Ian P. Henry. "Deconstructing the Debate around Sport and the 'Question' of 'Muslim Minorities' in the West”. In Islam in the West: Key Issues in Multiculturalism. Edited by Max Farrar, Simon Robinson, Yasmin Vallic and Paul Wetherly. London: Palgrave, 2012, pp. 138-53.

3. Mahfoud Amara, and Ian P. Henry. "Sport, muslim identities and cultures in the UK, an emerging policy issue: Case studies of Leicester and Birmingham.” European Sport Management Quarterly 10 (2010): 419-43. doi:10.1080/16184742.2010.502743.

4. Jocelyne Césari. When Islam and Democracy Meet: Muslims in Europe and in the United States. New York: Palgrave, 2004.

5. Alain Touraine. Un Nouveau Paradigme: Pour Comprendre le Monde Aujourd'hui. Paris: Fayard, 2005.

6. Alain Touraine. Can We Live Together? Equality and Difference. Cambridge: Polity Press, 2000.

6 According to BBC documentary on Muslims in the Premier league there are nearly 40 Muslim players in the English Premier league. 20 years ago there were none. 
7. Mouhamed Arkoun. The Unthought In Contemporary Islamic Thought. London: Saqi Books, 2002.

8. Leila Babes, and Tariq Oubrou. Loi d'Allah, loi des Hommes. Paris: Albin Michel, 2002.

9. Tariq Ramadan. Western Muslims and the Future of Islam. London: Oxford University Press, 2004.

10. Martin Riesebrodt. "Fundamentalism and the resurgence of religion." Numen 47 (2000): 266-87. http://www.jstor.org/stable/3270326.

11. Jürgen Habermas. “Notes on a post-secular society.” Signandsight.com, 18 June 2008. Available online: http://www.signandsight.com/features/1714.html (accessed on 1 September 2010).

12. Mouhamed Arkoun. "Rethinking Islam Today." Annals of the American Academy of Political and Social Science 588 (2003):18-39. http://www.jstor.org/stable/1049852.

13. Edward Said. Orientalism. London: Penguin, 1977.

14. Jocelyne Césari. Musulmans et Républicain: Les Jeunes, l'Islam et la France. Paris: Editions Complexe, 1998.

15. Jean-Paul Charnay. “Que devient une religion réduite à l'observance rituelle?” Oumma.com, 26 May 2000. Available online: http://oumma.com/Que-devient-une-religion-reduite-a (accessed on 5 November 2005).

16. Ahmed Akbar. Journey into Islam, The Crisis of Globalisation. Washington: Brookings Institution Press, 2007.

17. Peter Mandville. "Muslim transnational identity and state responses in Europe and the UK after 9/11: Political community, ideology and authority.” Journal of Ethnic and Migration Studies 35 (2009): 491-506. doi:10.1080/13691830802704681.

18. Ian Buruma, and Avishai Margalit. Occidentalism: The West in the Eyes of its Enemies. New York: Penguin Books, 2004.

19. PewResearch. "Religion and public life style: The future of the global Muslim population.” 2010. Available online: http://www.pewforum.org/2011/01/27/future-of-the-global-muslim-populationregional-europe/\#ftn35_rtn (accessed on 1 September 2013).

20. Jocelyne Césari. "Islam in France: The Shaping of a Religious Minority.” In Muslims in the West, from Sojourners to Citizens. Edited by Yvonne Haddad-Yazbek. London: Oxford University Press, 2002, pp. 36-51.

21. Michel Veron. "Aubry a-t-elle vraiment réservée des créneaux de piscine à des musulmans.” L'express Magazine, 30 March 2012. Available online: http://www.lexpress.fr/actualite/politique/ aubry-a-t-elle-vraiment-reservee-des-creneaux-de-piscine-a-des-musulmanes_1098551.html (accessed on 1 December 2012).

22. Ugo Palheta. "Coupe du Monde: Alain Finkielkraut moralise le football." $A C R I M E D$, 24 June 2010. Available online http://www.acrimed.org/article3400.html\# (accessed on 23 September 2012).

23. Pascal Duret. "Perception du « coup de Boule » de Zidane par les collégiens.” Socio-Logos. Revue de l'association Française de Sociologie 2, 2007. http://socio-logos.revues.org/171.

24. Bruce Crumley. "Booing the marsellaise: A French soccer scandal.” TIME Magazine, 15 October 2008. Available online: http://www.time.com/time/world/article/0,8599,1850831,00.html (accessed on 1 March 2011).

25. Le Point Magazine. "Marine Le Pen: 'Certains joueurs de l'équipe de France ont une autre nationalité de cœur’” 3 June 2010. Available online: http://www.lepoint.fr/societe/reaction- 
marine-le-pen-certains-joueurs-de-l-equipe-de-france-ont-une-autre-nationalite-de-coeur-03-062010-462559_23.php_(accessed on 10 October 2012).

26. Dan Baynes, and Gregroy Viscus. "French Team Faces Fight to Improve Its Image after World Cup 'Disaster'." Bloomberg Online, 23 June 2010. Available online: http://www.bloomberg.com/news/2010-06-22/french-team-faces-fight-to-improve-its-image-afterworld-cup-disaster-.html (accessed on 15 October 2012).

27. Robert Marquand. "France's World Cup soccer woes rock French society.” The Christian Science Monitor, 22 June 2010. Available online: http://www.csmonitor.com/World/Europe/2010/0622/ France-s-World-Cup-soccer-woes-rock-French-society (accessed on 20 September 2011).

28. Feteh Mezzener. "Les joueurs musulmans de l'équipe de France de foot mangent-ils réellement Halal?” Oumma.com, 12 June 2012. Available online http://oumma.com/13059/joueursmusulmans-de-lequipe-de-france-de-foot-mangent (accessed on 13 October 2012).

29. Bénédicte Charles. "Incroyable mais vrai: Avec Domenech, c’était halal pour tous les bleus!” Marianne Magazine, 8 September 2010. Available online: http://www.marianne.net/Incroyablemais-vrai-avec-Domenech-c-etait-halal-pour-tous-les-bleus-_a197168.html (accessed on 15 January 2012).

30. Karam Saër. “Djamel Bouras: Le combattant de la vérité.” La Revue du Liban, 20 January 2001. Available online: http://www.rdl.com.lb/2001/q1/3775/bouras.html\# (accessed on 10 June 2013).

31. Mahfoud Amara. Sport, Politics and Society in the Arab World. London: Palgrave and Macmillan, 2012.

32. BBC. “The Muslim Premier League.” BBC Documentary, broadcasted on 9 July 2013 (duration 30 min). Available online: http://www.bbc.co.uk/programmes/b036qfqc_(accessed on 9 July 2013).

33. Jill Reilly. "Publisher arrested in Tunisia after printing GQ cover of German footballer covering naked WAG's breasts with his hands.” Daily Mail, 24 February 2012. Available online: http://www.dailymail.co.uk/news/article-2105892/Publisher-arrested-Tunisia-GQ-cover-Germanfootballer-Sami-Khedira-covering-Lena-Gerckes-breasts.html\#ixzz2ZDpNcyf6 (accessed on 15 September 2012).

34. Luc Bronner. “La place croissante de l’islam en banlieue.” Le Monde, 4 October 2011. Available online: http://www.lemonde.fr/societe/article/2011/10/04/banlieues-de-la-republique_1581976_ 3224.html (accessed on 10 September 2012).

(C) 2013 by the author; licensee MDPI, Basel, Switzerland. This article is an open access article distributed under the terms and conditions of the Creative Commons Attribution license (http://creativecommons.org/licenses/by/3.0/). 